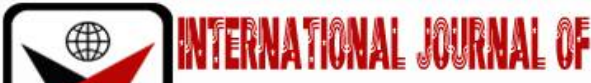

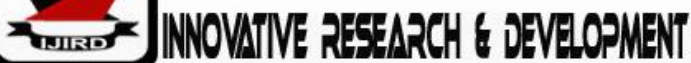

ISSN 2278 - 0211 (Online)

\section{Determinants of Profitability of General Insurance Companies in Indonesia}

Said Djamaluddin
Postgraduate Lecturer, Mercu Buana University, Jakarta, Indonesia
Budiman
Postgraduate Alumni, Mercu Buana University, Jakarta, Indonesia
Aty Herawaty
Postgraduate Lecturer, Mercu Buana University, Jakarta, Indonesia

\section{Abstract:}

This study aims to analyze the factors that affect the profitability of general insurance companies in Indonesia. The research population consisted of conventional general insurance companies that obtained operating licenses in Indonesia from the Financial Services Authority (OJK) during the 2012-2017 observation period. The study sample consisted of 69 companies determined by purposive sampling. The study uses secondary data from the annual Indonesian Insurance Statistics issued by the Financial Services Authority (OJK). The research method used was descriptive statistic and panel data regression with the Generalized Least Square (GLS) statistical method using the Random Effect Model (REM). The results showed that Leverage and Underwriting Risk had a significant negative effect on Return on Assets, Company Size had a significant positive effect on Return on Assets, while Liquidity and Tangibility had no effect on Return on Assets. The implication in this study is that companies need to maintain and reduce the ratio of Leverage and Underwriting Risk, because both are proven to have a negative effect on profitability. Besides, the company needs to increase the Company Size, because it is proven to have a positive effect on profitability.

Keywords: Leverage, liquidity, tangibility, company size, underwriting risk

\section{Introduction}

Insurance as a business that offers financial protection for life, health, wealth or other financial interests for insurance service users (individuals or companies) for the risk of unexpected events that cause death, illness, loss or damage to insured interests as compensation for premium that has been paid. Insurance businesses have characteristics that are different from other types of business services, because insurance businesses take over various risks from other parties so that insurance companies become risky if not managed properly (Kirmizi and Agus, 2011).

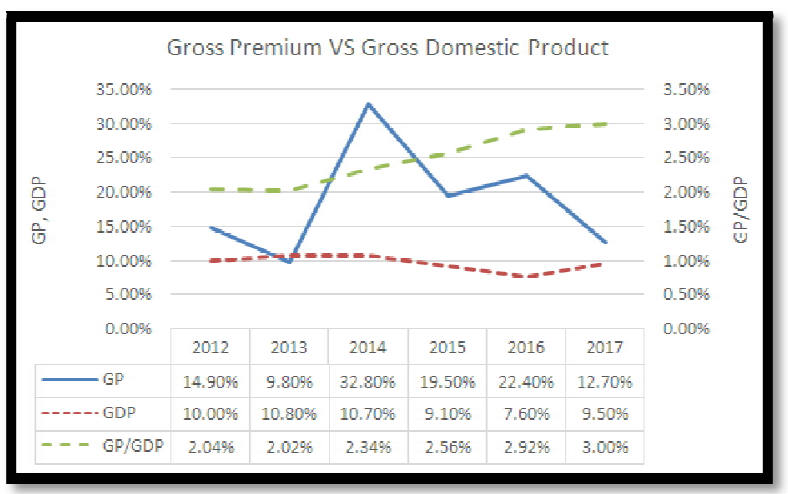

Figure 1: Growth of Gross Premium and Gross Domestic Product 2012-2017

Source: Indonesian Insurance Statistics 2016 \& 2017

Based on data obtained from the Indonesian Insurance Statistics 2017 issued by the Financial Services Authority (OJK) as in Figure 1, the receipt of Gross Premium (GP) in the insurance industry in 2017 increased 12.7\% compared to 2016. While in the same period the Indonesian economy, if measured by Gross Domestic Income (GDP), in 2017 it increased 9.5\% compared to 2016. The ratio of GP to GDP has increased from 2.92\% in 2016 to $3.0 \%$ in 2017. In the last 
six years, GP average growth is around $18.68 \%$ compared to GDP average growth of around $9.62 \%$. The growth of GP insurance industry revenues in fluctuating conditions with the highest growth in 2014 was $32.8 \%$, while the lowest growth occurred in 2013 at 9.8\%. On the one hand, GDP growth in fluctuating conditions with the highest growth in 2014 was $10.8 \%$ and the lowest in 2016 was 7.6\%. In general, the growth of GP revenues is above GDP growth except in 2013, as well as the GP revenue ratio compared to GDP continues to increase except in 2013.

The following is a table of growth in the number of insurance industry companies in Indonesia for each type of insurance business from 2012 to 2017:

\begin{tabular}{|c|c|c|c|c|c|c|c|}
\hline $\mathbf{N r}$ & Description & $\mathbf{2 0 1 2}$ & $\mathbf{2 0 1 3}$ & $\mathbf{2 0 1 4}$ & $\mathbf{2 0 1 5}$ & $\mathbf{2 0 1 6}$ & $\mathbf{2 0 1 7}$ \\
\hline 1. & Life Insurance & 47 & 49 & 50 & 55 & 55 & 61 \\
\hline & a. National Private & 28 & 30 & 31 & 33 & 31 & 37 \\
\hline & b. Joint Venture & 19 & 19 & 19 & 22 & 24 & 24 \\
\hline 2. & General Insurance & 84 & 82 & 81 & 80 & 80 & 79 \\
\hline & a. National Private & 66 & 65 & 64 & 64 & 58 & 55 \\
\hline & b. Joint Venture & 18 & 17 & 17 & 16 & 22 & 24 \\
\hline 3. & Reinsurance & 4 & 4 & 5 & 6 & 6 & 7 \\
\hline & a. National Private & 4 & 4 & 5 & 6 & 6 & 7 \\
\hline & b. Joint Venture & - & - & - & - & - & - \\
\hline 4. & Social Security Administrator & 2 & 2 & 2 & 2 & 2 & 2 \\
\hline 5. & Mandatory Insurance Organizer & 3 & 3 & 3 & 3 & 3 & 3 \\
\hline 6. & Total (1 to 5) & 140 & 140 & 141 & 146 & 146 & 152 \\
\hline 7. & Insurance Broker & 150 & 169 & 157 & 166 & 169 & 169 \\
\hline 8. & Reinsurance Broker & 29 & 29 & 31 & 37 & 40 & 43 \\
\hline 9. & Insurance Loss Adjuster & 26 & 25 & 26 & 28 & 28 & 27 \\
\hline 10. & Total (7 to 9) & 205 & 207 & 214 & 231 & 237 & 239 \\
\hline 11. & Total (6 +10) & 345 & 347 & 355 & 377 & 383 & 391 \\
\hline
\end{tabular}

Table 1: Growth of Number of Insurance Companies 2012-2017

Source: Indonesian Insurance Statistics 2016 \& 2017

From Table 1 we can see the number of insurance companies that have business licenses to operate in Indonesia as of December 31, 2017, which are 391 companies, consisting of 152 insurance and reinsurance companies and 239 insurance business support companies. Insurance and reinsurance companies consist of 61 life insurance companies, 79 general insurance companies, 7 reinsurance companies, 2 social security program administrators, and 3 compulsory insurance companies. In the past six years, foreign investment in the form of joint ventures increased from 19 life insurance companies and 18 general insurance companies in 2012 to 24 life insurance companies and 24 general insurance companies in 2017.

The company's performance ability is because it is a component of financial statements that are used as a tool to assess good or not of a company's performance. The results of the policies and decisions taken by management in running the company. These factors are represented by company-specific characteristics and external factors with respect to industry and macroeconomic variables. One financial ratio to measure the level of profit or profitability of a company is Return on Assets (ROA). As presented in Figure 2, during the period 2012-2017, ROA of General Insurance business fluctuated with the highest growth in 2012 at $5.81 \%$ and the lowest in 2017 at 3.59\%. ROA of Life Insurance business fluctuated with the highest growth in 2014 at $4.55 \%$ and the lowest in 2013 at $1.02 \%$. While the ROA of Reinsurance business fluctuated with the highest growth in 2015 at 8.66\% and the lowest in 2013 at 3.09\%. the highest ROA during 2012 to 2017 was Reinsurance business at 6.30\%, followed by General Insurance business at $4.69 \%$ and Life Insurance business at 2.94\%. ROA of General Insurance Business in general is better than ROA of Life Insurance business.

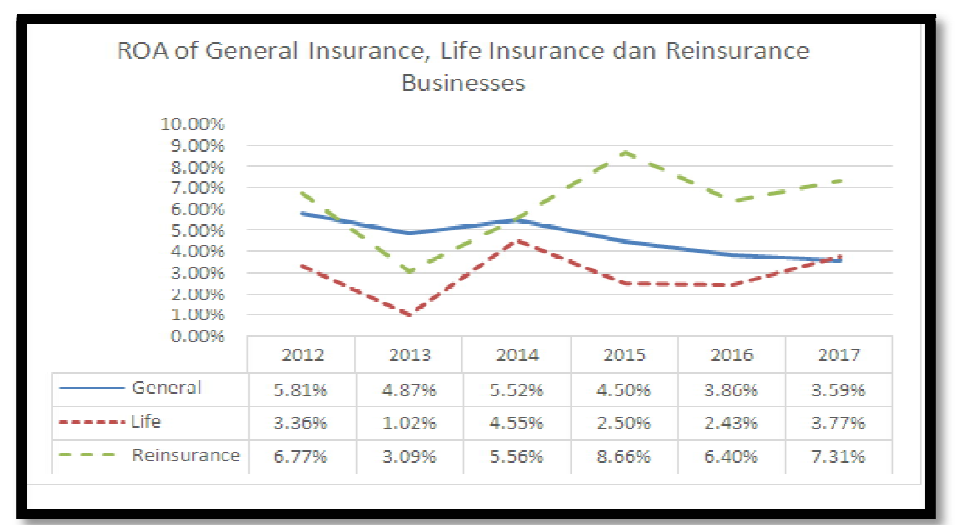

Figure 2: ROA of General Insurance, Life Insurance and Reinsurance

Businesses 2012-2017

Source: Processed By Researcher 
This study focused on obtaining empirical evidence on the relationship between the profitability of general insurance companies in Indonesia as measured by the ratio of Return on Assets as the dependent variable and five company-specific factors (Leverage, Liquidity, Tangibility, Company Size and Underwriting Risk) as independent variables.

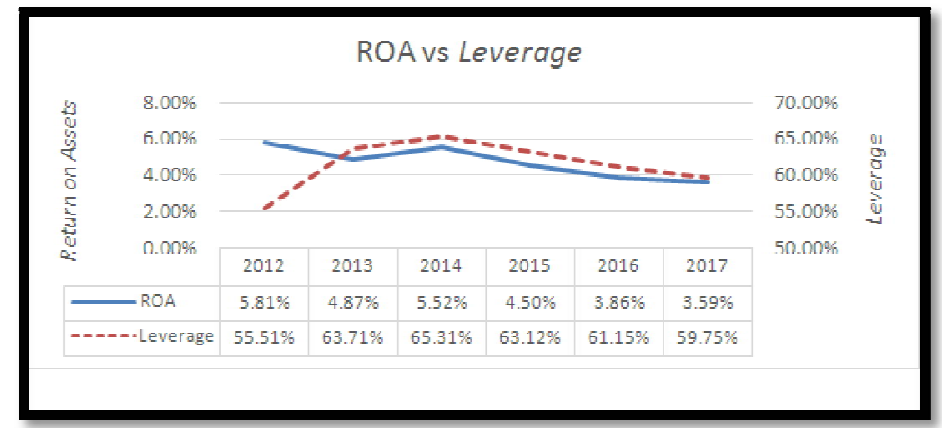

Figure 3: ROA and Leverage of General Insurance Business 2012-2017 Source: Processed by Researcher

Figure 3 shows in 2013 Leverage has increased, while ROA has decreased, in 2014 Leverage and ROA have both increased for the following year both have decreased, this indicates an alleged positive relationship between leverage and ROA. Figure 4 shows that in 2013-2015 the fluctuations in the development of Liquidity and ROA were inversely proportional while in 2016 and 2017 both experienced a decline; this indicates an alleged negative relationship between Liquidity and ROA.

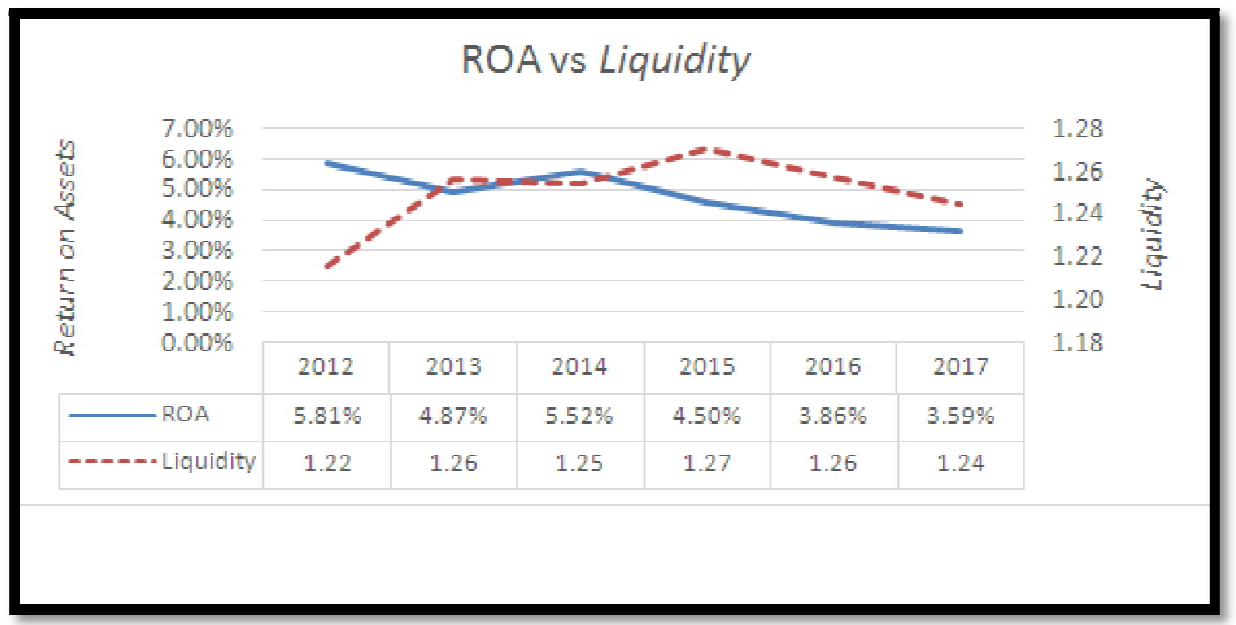

Figure 4: ROA and Liquidity of General Insurance Business 2012-2017 Source: Processed by Researcher

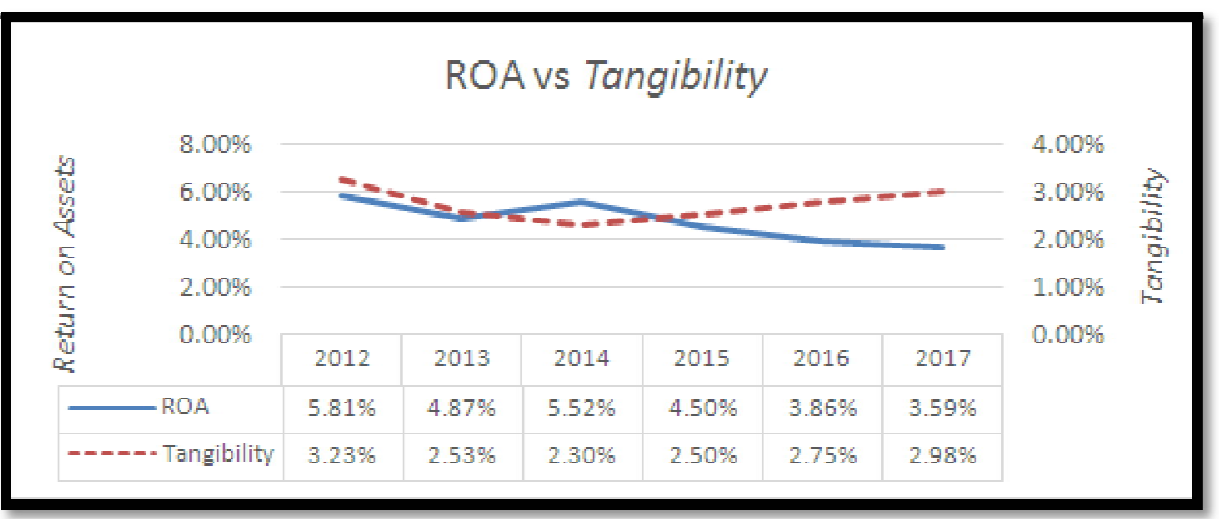

Figure 5: ROA and Tangibility of General Insurance Business 2012-2017 Source: Processed by Researcher

Figure 5 shows the Tangibility and ROA dropped in 2013, but both fluctuations are inversely proportional to the following years, this indicates an alleged negative relationship between Tangibility and ROA. 


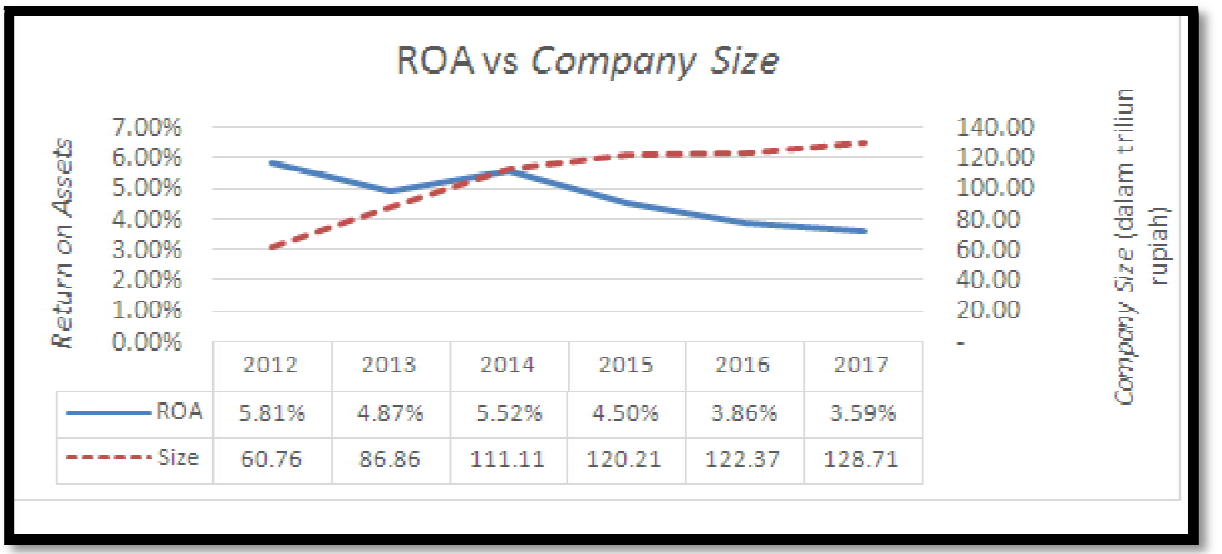

Figure 6: ROA and Company Size of General Insurance Business 2012-2017

Source: Processed by researcher

Figure 6 shows the tendency of Company Size to continue to increase during the period 2012-2017, while the tendency of ROA continues to decline except for 2014; this indicates an alleged negative relationship between Company Size and ROA.

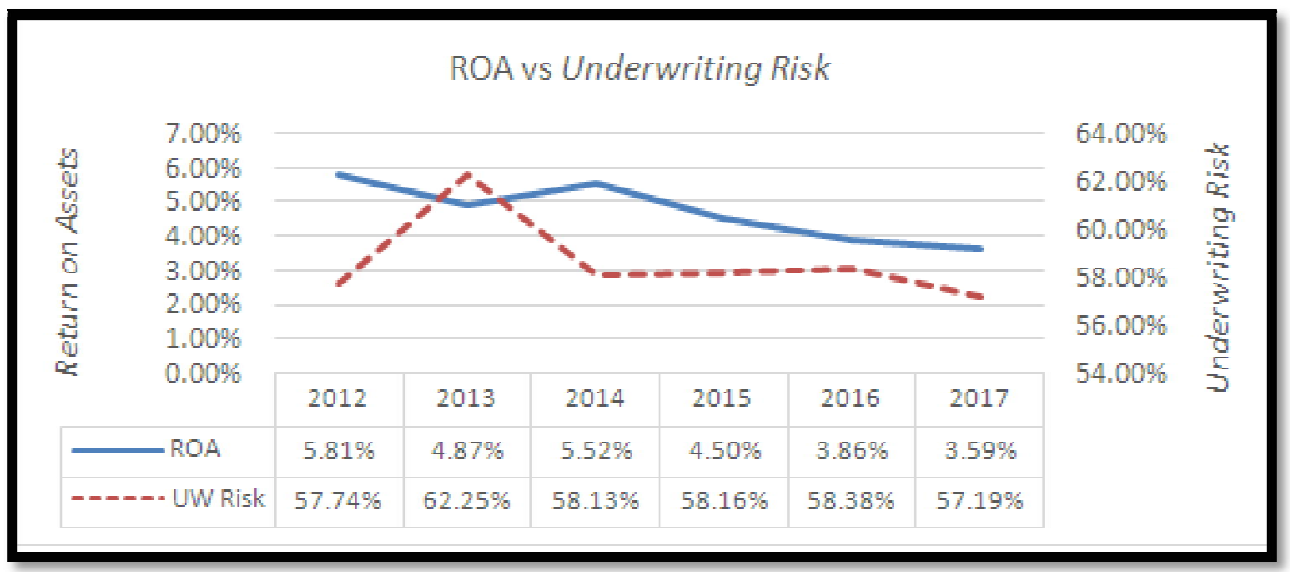

Figure 7: ROA and Underwriting Risk of General Insurance Business 2012-2017 Source: Processed by Researcher

Figure 7 shows the Underwriting Risk tendency is decreasing, but the fluctuations are inversely proportional to the fluctuations in ROA except for 2017, this shows an alleged negative relationship between Underwriting Risk and ROA. Based on the background above, identification of problems can be summarized as follows: (1) Growth in the premium income of the insurance industry in Indonesia fluctuates and averages above the growth of Gross Domestic Product throughout the period of 2012 to 2017, except for 2013. (2) Amount General insurance declined to 79 companies in 2017 from 84 companies in 2012, while the number of foreign investments in joint ventures increased mainly in general insurance companies to 24 companies in 2017 from 17 companies in 2012. (3) ROA of General Insurance business is above the ROA of Life Insurance business in 2012-2016, whereas in 2017 the opposite is true. (4) ROA and leverage, initially in the opposite direction, but then fluctuate in the same direction; (5) ROA and Liquidity, fluctuating in opposite directions. (6) ROA and Tangibility are initially in the same direction, but then fluctuate in opposite directions. (7) ROA and Company Size, fluctuating in opposite directions except in 2014. (8) ROA and Underwriting Risk, fluctuating in opposite directions except in 2017. Based on the background and identification of problems stated above, the problem can be formulated in this study as follows: (1) Does Leverage affect Return on Assets of general insurance companies in Indonesia? (2) Does Liquidity affect Return on Assets of general insurance companies in Indonesia? (3) Does Tangibility affect the Return on Assets of general insurance companies in Indonesia? (4) Does the Company Size affect Return on Assets of general insurance companies in Indonesia? (5) Does Underwriting Risk affect Return on Assets of general insurance companies in Indonesia?

\section{Theoretical Review}

Pecking Order Theory was first introduced by Donaldson in 1961 in its survey of companies in the United States. In the journal The Capital Structure Puzzle (Myers, 1984) states that there is a kind of pecking order for companies to use capital, that is, companies prefer internal financing (funding from the company's operating results in the form of retained earnings) rather than external financing (issuing shares new). The use of retained earnings is cheaper and the company does not need to disclose a number of company information that must be disclosed when issuing bonds or new shares.

The order of funding according to the pecking order theory is:

- Companies prefer internal financing 
- The company adjusts the dividend payout ratio target to investment opportunities and avoids drastic dividend changes.

- A "sticky" dividend policy plus fluctuations in profitability and unpredictable investment opportunities, means that sometimes internal cash flow will exceed investment requirements but also sometimes can be less than investment decisions.

- If external funding is needed, the company will first issue the safest securities, starting with the issuance of bonds (debt), convertible bonds and the last alternative is securities.

Marsh (1982) developed the modern capital structure theory proposed by Modigliani and Miller (1958). The static concept of a trade-off theory states that companies base funding decisions on an optimal capital structure. This theory explains the maximum value of the company if the company uses $100 \%$ debt because interest paid due to using debt can reduce taxable income or tax deductibles (Mutamimah and Rita, 2009). But in practice, companies with funding using $100 \%$ debt have never been found. In fact, the greater the debt the higher the burden that must be borne by the company because of the agency cost, the cost of bankruptcy, the reluctance of creditors to give large debts, and so on. The trade-off theory states that the optimal capital structure is achieved when there is a balance between the benefits of using debt and the cost of using debt. The benefits of using debt are tax shield. Costs of using debt include debt interest expense, bankruptcy costs, and agency cost.

The implications of the trade-off theory are:

- Companies with big business risks must use less debt than companies that have low business risk, because the greater the business risk, the greater use of debt will increase the interest expense, which will further complicate the company's finances.

- Companies that are subject to high taxes at certain limits should use a lot of debt because of the tax shield.

- The target debt ratio will differ from company to company. Companies that are profitable and have more tangible assets target higher debt ratios than companies that are not profitable and have more intangible assets.

Agency Theory explains the relationship between the agent and the principal. Agent is the management of the company while the principal is the owner (shareholder). Agency theory describes the separation of company property rights and responsibility for decision making (Jensen and Meckling, 1976). Agency relations always cause problems between owners and agents because of differences in mindset and prominent differences in interests.

The relationship between agency theory and working capital management can be seen from the perspective of financial managers, where a financial manager acts as an agent of the owner (principal) of the company. Financial managers make all decisions related to the company's short-term assets and debt (Aminu and Zainudin, 2015). The financial manager manages the accounts receivable, debt and inventory of the company. When viewed from a broader perspective, financial managers act as agents between company owners and stakeholders. Creditors lend to companies and expect to receive scheduled and timely debt repayments. The shareholders invest in the company and hope to get the maximum profit. Employees work in companies and want appropriate compensation and remuneration. Customers as a source of income for the company want goods and services provided by the company according to the price paid. Suppliers supply goods / services to companies and expect to get trustworthy buyers and pay on time. The financial manager acts as an agent between the owner of the company and creditors, shareholders, employees, customers and suppliers.

Increased conflict of interest because the principal cannot monitor the activities of agents on a daily basis to ensure that the agent works according to the wishes of the shareholders. Instead, the agent himself has a lot of important information about his capacity, work environment and company as a whole. This is what triggers an imbalance of information between the principal and the agent. This condition is called information asymmetry.

Information asymmetry arises when managers know more about internal information and company prospects in the future than shareholders or other stakeholders. Thus certain consequences will only be known by other parties who also need that information. Information asymmetry can occur between two extreme conditions, namely small differences in information so that it does not affect management or very significant differences that greatly affect management and stock prices. The potential impact of information asymmetry is the emergence of market failures.

Asymmetric information is the assumption that investors and managers have different information (which is better) about the company's prospects than those owned by investors. It is known that company managers must know more about information relating to the condition and prospects of the company compared to investors or analysts. There are two types of information asymmetry, namely:

- Adverse selection is a type of information asymmetry in which one or more parties that hold or will carry out a business transaction, and potential business transactions have more information on other parties. Adverse selection occurs because some people such as company managers and other insiders are more aware of the current conditions and prospects for the future of a company than investors. Ways that can be used by managers and other insiders in utilizing excess information at the expense of outside parties such as by refracting or managing information conveyed to investors. If investors know that the information submitted is biased information, then they will be careful in buying company securities, which results in the capital market and market managers not functioning as they should.

- Moral hazard is a problem that arises if the agent does not implement things that have been agreed upon in the employment contract. It can occur because of the separation of ownership with control which is characteristic of most large companies where the management knows better than other parties.

Information imbalances generally can occur because of buying and selling transactions between brokers and investors, where brokers experience a lack of information and on the other hand investors have a lot of information. In 
addition, information imbalances can also occur if the company's shares are considered too high or too low from its market value.

According to Myers and Majluf (1977) there is information asymmetry between managers and outsiders, managers have more complete information about the condition of the company compared to outside parties. When stock prices show a very high value (over value) managers will tend to issue shares (using prices that are too high). Of course, outside parties (markets) do not want to be deceived, because at the announcement of new shares, prices are announced as the market interprets stock prices over value. The theory can explain the phenomenon of falling stock prices in the event of an announcement of the issuance of new shares.

Profitability is the company's ability to generate profits for a certain period. In addition to being an indicator of the company's ability to fulfill its obligations for persons with funds, the company's profit is also an element in the creation of corporate value that shows the company's prospects in the future. According to Horne and Wachowicz (2012: 37) profitability consists of (1) Gross profit margin or gross profit margin which is a profitability measurement ratio used to determine the gross profit of the company that comes from the sale of each product. (2) Net profit margin which is a measure of the company's profitability from sales after calculating all costs and income taxes. (3) Return on Assets (ROA) shows the company's ability to generate profits from assets used. In this study profitability is measured by the ratio of Return on Assets (ROA), which is the balance ratio of net income after tax and total assets.

Solvability ratio or leverage ratio is a ratio used to regulate the extent to which a company's activities are financed by debt (Kasmir, 2010: 151). While according to Irham Fahmi (2011: 62) leverage ratio is the ratio used to measure how much the company is financed with debt. In insurance, the level of financial leverage reflects the ability of insurance companies to manage their economic exposure to unexpected losses. This ratio is a potential impact on capital and a surplus in reserves due to financial claims. (Adams and Buckle, 2003).

Liquidity is related to the problem of the company's ability to fulfill its financial obligations that must be fulfilled immediately. According to Harahap (2012: 301) liquidity ratio is a ratio that describes the company's ability to complete its short-term obligations.

Tangibility (asset / wealth structure) is the determination of how much the total allocation of funds is each component of current assets and fixed assets. According to Riyanto (2010: 22) states "the structure of wealth is a balance both in terms of absolute and in the relative sense between current assets and fixed assets". Whereas according to Husnan and Pudjiastuti (2012: 6) investment decisions will be reflected on the assets side of the company, thus affecting the structure of corporate wealth, namely the comparison between current assets and fixed assets.

Company Size can be expressed in total assets, sales and market capitalization. The size of the company in this study is measured by the total assets of the company. The definition of total assets is all resources controlled by the company as a result of past transactions and are expected to provide economic benefits for the company in the future (IAI, 2002).

Underwriting risk reflects the adequacy, or vice versa, of the insurance company's insurance performance. Guidance on guarantee is more important, very important for the financial performance of insurance companies. Underwriting risk depends on the risk appetite of the insurance company. The benefit ratio borne for net premiums is a measure of underwriting risk (Adams and Buckle, 2003). follows:

From the explanations presented above, the schema of the conceptual framework of this study can be described as

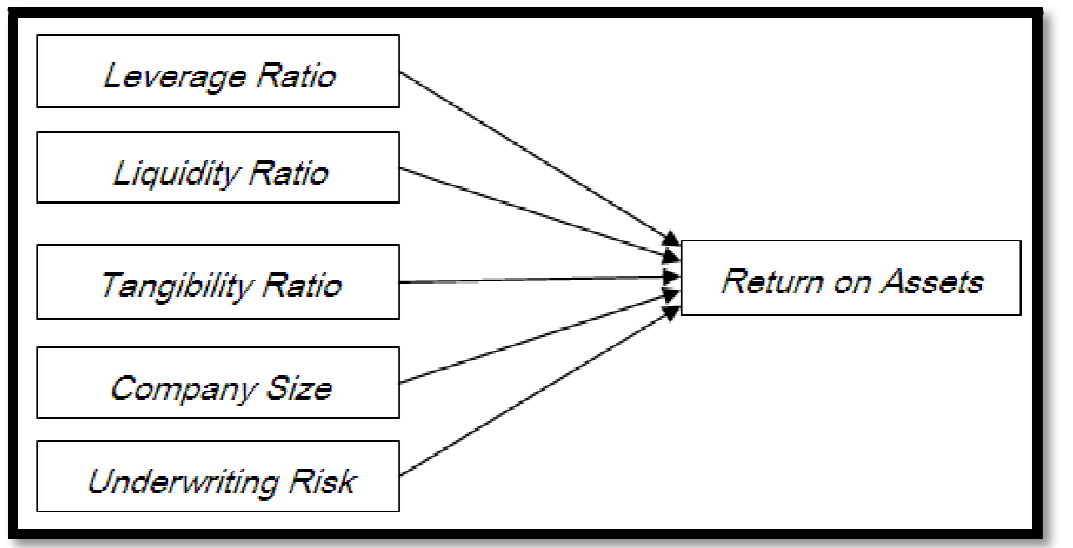

Figure 8: Framework

Source: Processed by researcher

Based on the formulation of the problem and empirical studies that have been done, it can be hypothetically drawn as follows:

- H1: Leverage is alleged to have a negative effect on Return on Assets.

The increase in the debt ratio has a negative effect on profitability. The negative relationship between leverage and profitability is reinforced by the results of the research of Ahmed et al. (2011), Javaria et al. (2013) and Çekrezi (2015) which state that Leverage has a significant negative effect on profitability.

H2: Liquidity is alleged to have a positive effect on Return on Assets. 
The increase in current ratio has a positive effect on profitability. This positive relationship between Liquidity and Profitability is reinforced by the results of the research of Charumathi (2011) and Almajali et al. (2012) which states that Liquidity has a significant positive effect on profitability.

- H3: Tangibility is alleged to have a positive effect on Return on Assets.

The increase in fixed asset ratio has a positive effect on profitability. This positive relationship between Tangibility and Profitability is reinforced by the results of research conducted by Mehari and Aemiro (2013) and Çekrezi (2015) which state that Tangibility has a significant positive effect on profitability.

- H4: Company Size is alleged to have a positive effect on Return on Assets.

The increase in company size has a positive effect on profitability. This positive relationship between Company Size and Profitability is made clear by the results of the research by Almajali et al. (2012), Mehari and Aemiro (2013) and Burca and Batrînca (2014) which stated that Company Size has a significant positive effect on profitability.

- H5: Underwriting Risk is alleged to have a negative effect on Return on Assets.

The increase in the claim load ratio has a negative effect on profitability. The negative relationship between Underwriting Risk and Profitability is made clear by the results of the research of Mehari and Aemiro (2013), Lee (2014), Burca and Batrînca (2014) and Rich (2015) which stated that Underwriting Risk significantly negatively affected profitability.

\section{Method}

In accordance with the research problems described earlier, the research design used is quantitative and causal. Quantitative research design is a research design that is deductive, objective and scientific, while causal design seeks to know the relationship of one variable to another variable. This study aims to examine the effect of independent variables namely leverage, tangibility, liquidity, company size, and underwriting risk on the dependent variable, Return on Assets. Data collection uses research instruments, data analysis is quantitative / statistical, with the aim of testing the hypotheses that have been set. The data analysis technique in this study is to use panel data regression analysis including: (1) descriptive analysis, (2) panel data quality analysis, (3) inferential data analysis. The level of significance in this study was set at $\alpha=5 \%(0.05)$. While the unit of analysis in this study is conventional general insurance companies in Indonesia with the 2012-2017 research period.

The variables used in this study consisted of independent variables and dependent variables. The independent variable is a variable whose value affects the behavior of the dependent variable. While the dependent variable is a variable whose value is influenced by independent variables. The following is a table of operationalization of variables to determine the measurement and measurement scale of the variables involved in this study.

\begin{tabular}{|c|c|c|}
\hline Variable & Measurement & Scale \\
\hline 1. Return on Assets (ROA) & $\frac{\text { Net Income After Tax }}{\text { Total Assets }}$ & Ratio \\
\hline 2. Leverage (LV) & $\frac{\text { Total Debts }}{\text { Total Assets }}$ & Ratio \\
\hline 3. Liquidity (LQ) & $\frac{\text { Current Assets }}{\text { Current Liabilities }}$ & Ratio \\
\hline $4 . \quad$ Tangibility (TG) & $\frac{\text { Fixed Assets }}{\text { Total Assets }}$ & Ratio \\
\hline 5. Company Size (SZ) & Natural Log of Total Assets & Ratio \\
\hline 6. Underwriting Risk (UR) & $\frac{\text { Claim Incurred }}{\text { Earned Premium }}$ & Ratio \\
\hline
\end{tabular}

Table 2: Operationalization of Variables

Source: Processed by researcher

The population of this study is a general insurance company that has a license to operate in Indonesia from the Financial Services Authority (OJK) until December 31, 2017 which is 79 companies. Furthermore, the determination of the sample in this study was carried out by purposive sampling as presented in table 3 .

\begin{tabular}{|c|c|c|}
\hline $\mathrm{Nr}$ & Description & Total \\
\hline 1 & $\begin{array}{c}\text { General insurance companies that obtain OJK licenses operate in Indonesia } \\
\text { until 31 December 2017. }\end{array}$ & 79 \\
\hline 2 & General insurance companies that are non-conventional. & $(3)$ \\
\hline 3 & General insurance companiesthat are established after 2012. & $(3)$ \\
\hline 4 & $\begin{array}{c}\text { General insurance companies that are in the status of terminating their } \\
\text { business activities or whose operating licenses have been revoked. }\end{array}$ & $(3)$ \\
\hline 5 & General insurance companies that are submited incomplete reports & $(1)$ \\
\hline 6 & Number of sample companies & 69 \\
\hline
\end{tabular}

Table 3: Sampling of Companies

Source: Processed by researcher 
The data in this study are quantitative secondary cross-section and time-series or panel data. Data collection techniques used are archival data collection techniques, namely by collecting data from related documents to be processed in accordance with the problem under study. Data is obtained by downloading from the http:/ / www.ojk.go.id website to obtain Indonesian insurance statistics published by OJK.

The analytical method that will be used to test the effect of independent variables on the dependent variable is to use the panel data method which is a combination of cross-section and time-series data. One step in this study is to determine the general model used by using the regression function analysis. The use of multiple regression functions is intended to capture the various possibilities of migration and the variables estimated to determine the effect of Leverage, Liquidity, Tangibility, Company Size and Risk Underwriting on Return on Assets.

\section{Results and Discussion}

In this study, sample determination was done by purposive sampling. With this method, the number of samples is 69 general insurance companies that meet the qualifications during the period 2012-2017. The variables used in this study are ROA, LV, LQ, TG, SZ and UR. To obtain an overview of these variables, a descriptive statistical analysis was carried out.

\begin{tabular}{|c|c|c|c|c|c|}
\hline Variable & N & Minimum & Maximum & Mean & Std. Dev \\
\hline ROA & 414 & -0.363852 & 0.424587 & 0.033358 & 0.059109 \\
\hline LV & 414 & 0.054633 & 1.152099 & 0.592988 & 0.177916 \\
\hline LQ & 414 & 0.590804 & 47.588060 & 4.931378 & 4.247755 \\
\hline TG & 414 & 0.000432 & 0.540522 & 0.046936 & 0.076702 \\
\hline SZ & 414 & 11.367430 & 16.309230 & 13.433390 & 1.191597 \\
\hline UR & 414 & -0.341532 & 4.646634 & 0.543073 & 0.391137 \\
\hline
\end{tabular}

Table 4: Descriptive Statistics ROA, LV, LQ, TG, SZ, Ur 2012-2017

Source: Processed By Researcher

ROA 2012-2017 has a standard deviation value of 0.0592 greater than the Mean of 0.0334 , this result shows a considerable variation in data. The lowest value is -0.3636, namely SLU (2013), while the highest value is 0.4246, namely KBINSURE (2013). This shows that the company's ability to generate profits from the total assets held during the period 2012 to 2017 ranges from -0.3636 to 0.4246 , companies with ROA performance above 0.0334 can be said to be better than the industry average.

LV 2012-2017 has a standard deviation value of 0.1779 smaller than the mean of 0.5930 , this result shows a fairly good distribution of data. The lowest value is 0.0546, namely MPM (2012), while the highest is 1.1521, namely SLU (2013). This shows that the level of company dependence on debt from total assets held during the period 2012 to 2017 ranges from 0.0546 to 1.1521 , companies with performance leverage below 0.5930 can be said to be better than the industry average.

LQ 2012-2017 has a standard deviation value of 4.2478 smaller than the Mean of 4.9314, this result shows a fairly good distribution of data. The lowest value is 0.5908, namely SAMSUNG (2012), while the highest is 47.5880, namely MPM (2012). This shows that the level of the company's ability to be able to fulfill its short-term obligations during the period 2012 to 2017 ranges from 0.5908 to 47.5880 , companies with Liquidity performance above 4.9314 can be said to be better than the industry average.

TG 2012-2017 has a standard deviation value of 0.0767 greater than the mean of 0.0469 , this result shows considerable variation in data. The lowest value is 0,0004, namely SUMTT (2017), while the highest value is 0.5405, namely ABB (2012). This shows that the composition of fixed assets against the overall assets of the company during the period 2012 to 2017 ranged from 0,0004 to 0,5405 , companies with Tangibility performance above 0,0469 can be said to be better than the industry average.

SZ 2012-2017 has a standard deviation value of 1.1916 smaller than the mean of 13.4334, this result shows a fairly good distribution of data. The lowest value is 11,3674, namely BESS (2012) with total assets of Rp. 86.46 billion, while the highest is 16.3092 namely ASKRINDO (2017) with total assets of Rp. 12.11 trillion. This shows that the total assets of the company during the period of 2012 to 2017 ranged from Rp. 86.60 billion to Rp. 12.11 trillion.

UR 2012-2017 has a standard deviation value of 0.3911 smaller than the Mean of 0.5431 , this result shows a fairly good distribution of data. The lowest value is -0.33415, which is BERIKIKARI (2017), while the highest is 4.6466, namely SUMMTT (2014). This shows that the level of claim expense against the company's premium income during the period of 2012 to 2017 ranged from - 0.3415 to 4.6466, companies with Underwriting Risk performance below 0.5431 can be said to be better than the industry average.

Stationary data is data that has a constant and constant variance over time and covariance between two data sequences of time depends on lags between two periods or not. Test statistics used in testing unit root panels consist of two types, namely the common unit root consisting of Levin, Lin and Chu (LLC) test statistics; and individual unit root consisting of Im, Pesaran and Shin (IPS) statistics, ADF - Fisher test and PP - Fisher test. The null hypothesis is tested on the existence of a shared unit root, and the acceptance of the null hypothesis indicates the existence of the same unit root. 


\begin{tabular}{|c|c|c|c|c|c|c|c|}
\hline Method & & ROA & LV & LQ & TG & SZ & UR \\
\hline Levin, Lin \& & Statistic & -43.5764 & -16.9321 & -37.3721 & -220.049 & -25.4303 & -75.5142 \\
Chu t & Prob. & 0.0000 & 0.0000 & 0.0000 & 0.0000 & 0.0000 & 0.0000 \\
\hline Im, Pesaran & Statistic & -8.09530 & -2.71455 & -6.36942 & -49.8070 & -11.2321 & -7.40978 \\
and Shin W-stat & Prob. & 0.0000 & 0.0033 & 0.0000 & 0.0000 & 0.0000 & 0.0000 \\
\hline ADF - Fisher & Statistic & 267.482 & 212.089 & 252.456 & 335.585 & 375.789 & 201.707 \\
Chi-square & Prob. & 0.0000 & 0.0001 & 0.0000 & 0.0000 & 0.0000 & 0.0003 \\
\hline PP - Fisher Chi- & Statistic & 328.065 & 266.399 & 288.834 & 421.183 & 593.816 & 234.300 \\
square & Prob. & 0.0000 & 0.0000 & 0.0000 & 0.0000 & 0.0000 & 0.0000 \\
\hline
\end{tabular}

Table 5: Panel Unit Root Test Result

Source: Processed By Researcher

Based on the test results of Levin, Lin and Chu (common unit root); and Im, Pesaran and Shin (IPS), ADF - Fisher and PP - Fisher (individual unit root) tests in Table 5, probability values calculated lower than the $5 \%$ significance level ( $p$ value $<5 \%$ ), then the null hypothesis is rejected for each variable. Thus it can be stated the possibility that the panel data used in this study is stationary.

In the analysis of the panel data model there are three types of approaches that can be used, namely the least square approach (Common Effect), Fixed Effect approach, and Random Effect approach. Then the most appropriate model is chosen by doing the Chow test (fixed or common), Hausman test (random or fixed) and Lagrange Multiplier (common or random). The chosen model must fulfill two of the three tests.

\begin{tabular}{|c|c|c|c|}
\hline Uji & Statistik & Probabilitas & Model Terpilih \\
\hline Chow Test & 241.354300 & 0.0000 & Fixed Effect \\
\hline Hausman Test & 2.834589 & 0.7255 & Random Effect \\
\hline LM(Breusch-Pagan) & 107.9787 & 0.0000 & Random Effect \\
\hline
\end{tabular}

Table 6: Chow Test, Hausman Test and Lagrange Multiplier

Source: Processed by researcher

From table 6 where the significance level of $\alpha=5 \%$, the Random Effect model is the most appropriate model to use, where this model is selected from the results of two tests carried out, namely the Hausman test and Lagrange Multiplier.

Although the panel data regression model chosen is Random Effect where estimation is done using the Generalized Least Square (GLS) method, which does not need to be tested for classical assumptions, it is better to test whether the formed model meets the BLUE (Best Linear Unbias Estimator) requirements. The classic assumption testing that needs to be done is a multicollinearity test. To detect the presence or absence of multicollinearity can be seen from the amount of Variance Inflation Factor (VIF) and Tolerance. The guideline for a multicollinearity-free regression model is to have a tolerance number close to 1 . The VIF limit is 10 , if the VIF value is below 10, there are no symptoms of multicollinearity (Gujarati, 2012: 432).

\begin{tabular}{|c|c|c|}
\hline Variable & Tolerance & VIF \\
\hline LV & .568 & 1.759 \\
\hline LQ & .731 & 1.367 \\
\hline TG & .813 & 1.231 \\
\hline SZ & .779 & 1.284 \\
\hline UR & .935 & 1.070 \\
\hline
\end{tabular}

Table 7: Collinearity Statistics

Source: Processed by Researcher

From the results of the collaborative statistics in table 7 it can be seen that the Tolerance value of all variables is close to 1, and the VIF value of all variables is less than 10. Thus it can be concluded that the model is free from the problem of multicollinearity.

\begin{tabular}{|c|c|c|c|}
\hline Variable & Koefisien & t-Statistik & Probabilias \\
\hline C & -0.052399 & -1.041079 & 0.2985 \\
\hline LV & -0.097709 & -3.703366 & 0.0002 \\
\hline LQ & -0.001125 & -1.358320 & 0.1751 \\
\hline TG & 0.010158 & 0.232375 & 0.8164 \\
\hline SZ & 0.011911 & 2.986511 & 0.0030 \\
\hline UR & -0.020688 & -2.944925 & 0.0034 \\
\hline $\mathrm{R}^{2}=0.065834 ;$ F-statistic $=5.750668 ;$ Prob(F-statistic) $=0.000038$ \\
\hline
\end{tabular}

Table 8: Data Panel Regression Results With Random Effect Model Source: Processed By Researcher 
From the regression results in table 8, it can be concluded that the Prob Value (F-Statistic) of 0.000038 on this model is smaller than the 0.05 significance level, thus it can be said that the regression model that is feasible is used to explain the influence of independent variables (LV, LQ, TG, SZ and UR) on the dependent variable (ROA). R-square value (R2) of 0.065834 shows that the proportion of independent variables (LV, LQ, TG, SZ and UR) on the dependent variable (ROA) is $6.58 \%$, while the remaining $93.42 \%$ is influenced by other variables that are not in the regression model.

From the regression results in table 8 the Random Effect Model panel data regression equation is also obtained as follows:

$\mathrm{ROA}_{\mathrm{it}}=\alpha+\beta 1 \mathrm{LV}_{\mathrm{it}}+\beta 2 \mathrm{LG}_{\mathrm{it}}+\beta 3 \mathrm{TG}_{\mathrm{it}}+\beta 4 \mathrm{SZ}_{\mathrm{it}}+\beta 5 \mathrm{UR}_{\mathrm{it}}+\varepsilon_{\mathrm{it}} ; \varepsilon_{\mathrm{it}}=\mathrm{u}_{\mathrm{i}}+\mathrm{v}_{\mathrm{t}}+\mathrm{w}_{\mathrm{it}}$

So that the panel data regression equation model can be formulated as follows:

$\mathrm{Y}=-0,0524-0,0978 \mathrm{LV}-0,0011 \mathrm{LQ}+0,0102 \mathrm{TG}+0,0119 \mathrm{SZ}-0,0207 \mathrm{UR}$
$(-1,0411) \quad(-3,7034)$
$(-1,3583)$
$(0,2324)$
$(2,9865)$
$(-2,9449)$

The numbers in parentheses are t-statistics with $\alpha=5 \%$.

\begin{tabular}{|c|c|c|}
\hline Independent Variable & Found Effect & Significance ( $\boldsymbol{\alpha}=\mathbf{5 \% )}$ \\
\hline Leverage (LV) & Negatif(-) & Signifikan \\
\hline Liquidity (LQ) & Negatif(-) & Tidak Signifikan \\
\hline Tangibility (TG) & Positif (+) & Tidak Signifikan \\
\hline Company Size (SZ) & Positif(+) & Signifikan \\
\hline Underwriting Risk (UR) & Negatif(-) & Signifikan \\
\hline
\end{tabular}

Table 9: Relationship of Dependent Variables to Independent Variable (ROA)

Source: Processed by researcher

The first hypothesis aims to examine the negative effect of leverage on ROA. The panel data regression results show that the Leverage variable has a significant negative effect on profitability, thus this result corresponds to the hypothesis statement that was built at the beginning. These results explain that companies with a low level of leverage have better operational performance than companies with high leverage. In relation to the Pecking Order Theory that the greater the ratio, indicates that the greater the cost that must be borne by the company to fulfill its obligations. Insurance companies have the characteristics of large business risks, therefore based on Trade-Off Theory, companies with a large business risk must use less debt than companies that have low business risk. Debt insurance companies generally consist of debt related to insurance contracts including technical reserves which are generally the largest component of the insurance company's debt. The results of this study are in line with the results of research by Ahmed et al. (2011), Charumathi (2011), Javaria et al. (2013), Sambasivam and Ayele (2013), Burca and Batrînca (2014), Lee (2014), Rich (2015), C Cekrezi (2015) and Alfian (2016) which stated that leverage has a significant negative effect on profitability.

The second hypothesis aims to examine the positive effect of Liquidity on ROA. The panel data regression results show that the Liquidity variable does not have a significant effect on profitability, thus this result is not in accordance with the hypothesis statement that was built at the beginning. These results indicate that Liquidity is not considered a strong variable to determine the profitability of general insurance companies in Indonesia. In relation to Agency Theory, financial managers of insurance companies that act as agents are always required to maintain sufficient liquidity of companies against the demands of obligations that must be paid immediately and fulfillment of the minimum required solvability level regulators, with these conditions often insurance company financial managers ignore the amount of returns that can generated from their current assets. The results of this study are in line with the results of research by Ahmed et al. (2011), Boadi et al. (2013), Mehari and Aemiro (2013), Javaria et al. (2013), Derbali (2014), Mwangi and Murigu (2015) and Çekrezi (2015) state that Liquidity does not have a significant effect on profitability.

The third hypothesis aims to examine the positive influence of Tangibility on ROA. The panel data regression results show that the Tangibility variable does not have a significant effect on profitability, thus this result does not correspond to the hypothesis statement that was built at the beginning. These results indicate that Tangibility is not considered a strong variable to determine the profitability of general insurance companies in Indonesia. Regarding the Agency Theory, financial managers of insurance companies that act as agents often prioritize the adequacy of liquidity rather than developing their fixed assets. The results of this study are in line with the results of research by Ahmed et al. (2011), Sambasivam and Ayele (2013) and Derbali (2014) state that Tangibility does not have a significant effect on profitability.

The fourth hypothesis aims to examine the positive influence of the Company Size on ROA. The panel data regression results show that Company Size variables have a significant positive effect on profitability, thus this result is in accordance with the hypothesis statement that was built at the beginning. These results indicate that the performance of a large general insurance company is better than a small general insurance company. The larger the size of the company increases the ability of competitiveness, service and capacity they have to expand the market, besides that it can increase its own retention of business obtained for the category of low / good risk so as to reduce the reinsurance premium burden. Regarding the Agency Theory, the agency relationship that occurs between the principal and agency has burdened the manager to account for the resources he manages. The greater the resources managed by the company, the greater the activity of a business venture. The results of this study are in line with the results of research by Charumathi (2012), Almajali et al. (2012), Akotey et al. (2013), Mehari and Aemiro (2013), Javaria et al. (2013), Sambasivam and Ayele (2013), Burca and Batrînca (2014), Kaya (2015), Kusumawati and Juniarti (2016) and Simbolon and Pangestuti (2017) where Company Size has a significant positive effect on profitability. 
The fifth hypothesis aims to examine the negative effects of Underwriting Risk on ROA. The panel data regression results show that the Underwriting Risk variable has a significant negative effect on profitability, thus this result is in accordance with the hypothesis statement that was built at the beginning. Underwriting Risk reflects the adequacy, or vice versa, of the performance of insurance company guarantees, thus the results of this study explain that companies with low Underwriting Risk levels have better operational performance than companies with high Risk Underwriting rates. Regarding Assyry Information, the existence of information asymmetry in insurance contracts can cause the insurance company to misjudge the risk it receives. The results of this study are in line with the results of the research of Mehari and Aemiro (2013), Lee (2014), Burca and Batrînca (2014) and Rich (2015) which state that Underwriting risk has a significant negative effect on profitability.

\section{Closing}

Based on the results of the analysis and discussion in this study, conclusions can be taken as follows:

- The results of testing the data using the Random Effect Model, obtained results based on the F test that the independent variables together have a significant effect on the dependent variable.

- Leverage variables have a significant effect and negatively correlate to the dependent variable Return on Assets.

- Liqudity variable does not affect the dependent variable Return on Assets.

- Tangibility variable does not affect the dependent variable Return on Assets.

- Company Size variable have a significant effect and are positively correlated to the dependent variable Return on Assets.

- Underwriting Risk variable has a significant effect and negatively correlates to the dependent variable Return on Assets.

Based on the results of the discussion and conclusions regarding the variables which include Leverage, Liquidity, Tangibility, Company Size, and Underwriting Ratio on Return on Assets of general insurance companies in Indonesia, the author tries to convey some suggestions as consideration:

- For investors, it is better to make an investment decision to review Leverage, Company Size and Underwriting Risk to Return on Assets of general insurance companies in Indonesia.

- For general insurance companies in Indonesia in determining Return on Assets, it is necessary to consider variables such as Leverage, Company Size and Underwriting Risk because through this study these variables have proven to influence Return on Assets. Leverage and Underwriting Risk levels need to be maintained and tried to go down, while the Company Size is strived to be continuously improved. The source of capital that comes from increasing equity is recommended, besides that in the underwriting process it is also recommended to be more prudent.

- Further researchers need to do further research by examining other variables that affect the condition of the company's profitability such as Risk Base Capital, Management Competency Index and Combined Ratio.

\section{References}

i. Adams, M. and Buckle, M. (2003), "The Determinants of Corporate Financial Performance in the Bermuda Insurance Market", Applied Financial Economics, Routledge, 13, 133-143. EBMS Working Paper EBMS/ 2000/ 12 (ISSN: 1470-2398)

ii. Ahmed, N, Ahmed, Z. \& Usman, A. (2011). "Determinants of Capital Structure: A Case of Life Insurance Sector of Pakistan". International Research Journal of Finance and Economics, 61:123-128

iii. IAkotey, J. O., Sackey, F. G., Amoah, L., \& Manso, R. F. (2013). "The financial performance of life insurance companies in Ghana". The Journal of Risk Finance. 14(3), 286-302.

iv. Alfian, Melisa Afida. (2016). "Analisis Pengaruh Faktor Yang Menentukan Profitabilitas Sektor Properti, Real Estate, Dan Konstruksi Bangunan Yang Terdaftar Di Bursa Efek Indonesia Periode 2010-2014". Journal of Management Science (JIM), Vol 4, No 1

v. Almajali, Amal Yassin., Sameer Ahmed Alamro \& Yahya Zakarea Al-Soub (2012). "Factors Affecting the Financial Performance of Jordanian Insurance Companies Listed at Amman Stock Exchange". Journal of Management Research. ISSN 1941-899X, Vol. 4, No. 2.

vi. Aminu, Yusuf dan Nasruddin Zainudin. 2015. "A Review of Anatomy of Working Capital Management Theories and the Relevant Linkages to Working Capital Components: A Theoretical Building Approach". European Journal of Business Management, Vol. 7, No. 2, hal 10-18.

vii. Aryanti, Fitri., Arief Tri Hardiyanto dan Patar Simamora. (2017). "Pengaruh Struktur Modal, Ukuran Perusahaan, Dan Pertumbuhan Perusahaan Terhadap Profitabilitas Pada Perusahaan Yang Tergabung Dalam LQ 45 Di Bursa Efek Indonesia Tahun 2013-2015”. Jurnal Online Mahasiswa (JOM) Bidang Manajemen, Vol 1, No 1

viii. Baltagi, Badi H. (2005). Econometric Analysis of Panel Data. Third Edittion. John Wiley \& Sons Ltd, Chichester

ix. Boadi, E. K., Antwi, S. \& Lartey, V. C. (2013). "Determinants of Profitability of Insurance Firms in Ghana". International Journal of Business and Sosial Research, Vol 3 No. 3

x. Burca, A. M., \& Batrinca, G. (2014). "The Determinants of Financial Performance in The Romanian Insurance Market". International Journal of Academic Research in Accounting, Finance and Management Sciences, 4(1), 299-308

xi. Çekrezi, A. (2015). "Determinants of Financial Performance of the Insurance Companies: a Case of Albania". International Journal of Economics, Commerce and Management, III (4), 1-10. 
xii. Charumathi, B. (2012). "On the Determinants of Profitability of Indian Life Insurers - An Empirical Study". Proceedings of the World Congress on Engineering, 1, 4-9.

xiii. Chen, Jian-Shen, Mei-Ching Chen, Wen-Ju Liao \& Tsung-Hsien Chen. (2009). "Influence of capital structure and operational risk on profitability of life insurance industry in Taiwan”. Journal of Modelling in Management, Vol. 4 No. 1, pp. 7-18.

xiv. Darmawi, Herman. (2006). Manajemen Asuransi. Jakarta: Bumi Aksara.

xv. Derbali, A. (2014). "Determinants of performance of insurance companies in Tunisia: the case of life insurance". International Journal of Innovation and Applied Studies, 6(1), 90-96.

xvi. Ernayani, Rihfenti., Nadi Hernadi Moorcy dan Sukimin. (2017). "Faktor-Faktor Yang Mempengaruhi Return On Assets (Studi Pada Bank Umum Syariah Di Indonesia Periode 2011-2016)”. Prosiding Seminar Nasional dan Call For Paper Ekonomi dan Bisnis, hal 284-293

xvii. Fahmi, Irham. (2011). Analisis Kinerja Keuangan. Lampulo: Alfabeta.

xviii. Ghozali, Imam. 2012. Aplikasi Analisis Multivariate dengan Program IBM SPSS. Yogyakarta: Universitas Diponegoro

xix. Gujarati, Damodar N. (2004). Basic Econometrics, Fourth Edition. The McGraw-Hill Companies. New York. (2012), Dasar-dasar Ekonometrika, Terjemahan Mangunsong, R.C., Salemba Empat, buku 2, Edisi 5, Jakarta.

xx. Harahap, Sofyan Syafri. (2011). Analisis Kritis Atas Laporan Keuangan. Jakarta: Raja Grafindo Persada.

xxi. Husnan, Suad., dan Enny Pudjiastuty. (2012). Dasar-dasar Manajemen Keuangan (Edisi 6). Yogyakarta: UPP STIM YKPN

xxii. Horne, James C. Van dan John M. Wachowicz Jr. (2012). Prinsip-prinsip Manajemen Keuangan (Edisi 13). Jakarta: Salemba Empat.

xxiii. Ismail, M. (2013). "Determinants of Financial Performance: The Case of General Takaful and Insurance Companies in Malaysia". International Review of Business Research Papers Issue, Pp, 9(6), 111-130.

xxiv. Kasmir. (2010). Pengantar Manajemen Keuangan. Edisi I. Jakarta: Kencana Media Group. (2012). Analisis Laporan Keuangan, PT. Raja Grafindo Persada, Jakarta

xxv. Kaya, E. (2015). "The Effects of Firm-Specific Factors on the Profitability of Non-Life Insurance Companies in Turkey". International Journal of Financial Studies, 3(1): 510-529.

xxvi. Kirmizi \& Susi Surya Agus. (2011). "Pengaruh Pertumbuhan Modal dan Aset Terhadap Rasio Risk Based Capital (RBC), Pertumbuhan Premi Neto dan Profitabilitas Perusahaan Asuransi Umun di Indonesia”. Pekbis Jurnal, Vol.3 No.1 Maret 2011: 391-405.

xxvii. Kusumawati, Ivana Teddy dan Juniarti. (2016). "Pengaruh Family Control Terhadap Profitabilitas dan Nilai Perusahaan Pada Industri Dasar dan Kimia". Business Accounting Review, Vol 2, No 1

xxviii. Lee, Chen-Ying. (2014). "The Effects of Firm Specific Factors and Macroeconomics on Profitability of PropertyLiability Insurance Industry in Taiwan". Asian Economic and Financial Review, vol. 4, issue 5, 681-691

xxix. Mutamimah dan Rita. (2009). "Keputusan Pendanaan: Pendekatan Trade-Off Theory dan Pecking Order Theory". Ekobis, Vol. 10, No. 1, hal 241-249.

xxx. Mehari, D., \& Aemiro, T. (2013). “Firm Specific Factors That Determine Insurance Companies'Performance in Ethiopia". European Scientific Journal, 9(10), 245-255.

xxxi. Mwangi, M. \& Murigu, J. W. (2015). "The Determinants of Financial Performance in General Insurance Companies in Kenya". European Scientific Journal, 11(1), 288-297.

xxxii. Otoritas Jasa Keuangan. 2012. "Statistik Perasuransian Indonesia".https:// www.ojk.go.id/id/ kanal/ iknb/ datadan-statistik/ asuransi/ Default.aspx_(Accessed on 23 September 2018)

xxxii. 2013. "Statistik Perasuransian Indonesia".https:// www.ojk.go.id/ id/ kanal/ iknb/ data-danstatistik/asuransi/Default.aspx(Accessed on23 September 2018) 2014. "Statistik Perasuransian Indonesia".https:// www.ojk.go.id/ id/ kanal/ iknb/ data-dan-statistik/ asuransi/ Default.aspx （Accessed on23 September 2018)

xxxiv. 2015. "Statistik Perasuransian Indonesia".https:// www.ojk.go.id/ id/ kanal/ iknb/ data-danstatistik/ asuransi/ Default.aspx

(Accessed on23 September 2018)

xxxv. 2016.“Statistik Perasuransian Indonesia”.https:// www.ojk.go.id/id/ kanal/ iknb/ data-danstatistik/ asuransi/ Default.aspx (Accessed on 23 September 2018)

xxxvi. 2017."Statistik Perasuransian Indonesia”.https:// www.ojk.go.id/ id/ kanal/ iknb/ data-danstatistik/ asuransi/ Default.aspx

(Accessed on 02 November 2018)

xxxvii. Qurays, Ayu Azizah., Jeni Susyanti dan Afi Rachmat. (2018). "Pengaruh Financial Leverage, Operating Leverage Dan Debt To Equity Ratio (DER) Terhadap Profitabilitas Perusahaan”. Jurnal Ilmiah Riset Manajemen, e-Jrm Vol. 07 No. 01

xxxviii. Sambasivam, Yuvaraj \& Abate Gashaw Ayele. (2013). "A Study On The Performance Of Insurance Companies In Ethiopia”. International Journal of Marketing, Financial Services \& Management Research, Vol.2, No. 7

xxxix. Simbolon, Tioro dan Irene Rini Demi Pangestuti. (2017). "Analisis Pengaruh Size, Equity Asset Ratio (EAR), NIM, LDRr, NPL, Dan Biaya Operasi Terhadap Profitabilitas Bank (Studi Pada BankUmum Go Public Indonesia, Malaysia, Philipina, Singapore Dan Thailand Periode 2012-2016)". Diponegoro Journal of Management, Vol 6, No 3

xl. Standar Akuntansi Keuangan/ Ikatan Akuntan Indonesia. 2002. Jakarta: Salemba Empat. 
xli. Sugiyono. (2013). Metode Penelitian Kuantitatif, Kualitatif dan R\&D. Bandung: Alfabeta. CV

xlii. Sukarya, Oyo dan Farah Margaretha. (2018). "Masih Tepatkah ROA Sebagai Pengukuran Kinerja Keuangan Industri Asuransi Di Indonesia?". Jurnal Manajemen dan Pemasaran Jasa, Vol 11, No 1

xliii. Sumaira, Bilal., Javaria Khan \& Tufail Sidra Amjad, (2013). “Determinants of Profitability Panel Data Evidence from Insurance Sector of Pakistan". Elixir International Journal, p. 14378-14382.

xliv. Sutrisno. (2012). Manajemen Keuangan Teori, Konsep dan Aplikasi. Yogyakarta: EKONISIA.

xlv. Tenggono, Alvin. (2016). "Analisis pengaruh struktur modal terhadap profitabilitas perusahaan manufaktur sektor barang konsumsi sub sektor farmasi yang tercatat di bursa efek indonesia pada tahun 2009 - 2014". Jurnal Bisnis dan Manajemen, Vol 52, No 11

xlvi. Undang-Undang Nomor 40 Tahun 2014 Tentang Perasuransian.

xlvii. Zulkarnaen, Zuliana. (2018). "Pengaruh Debt To Assets Ratio Terhadap Return On Asset Pada Perusahaan Asuransi Yang Terdaftar Di BEI Tahun 2010 - 2015". Warta Dharmawangsa, No. 56 